Article

\title{
Bioactive Flavone- $C$-Glycosides of the African Medicinal Plant Biophytum umbraculum
}

Anh Thu Pham ${ }^{1, *}$, Celine Nguyen ${ }^{1}$, Karl Egil Malterud ${ }^{1}$, Drissa Diallo ${ }^{2}$ and Helle Wangensteen ${ }^{1, *}$

1 Section of Pharmaceutical Chemistry, School of Pharmacy, University of Oslo,

P.O. Box 1068 Blindern, N-0316 Oslo, Norway; E-Mails: nguyen.celine@gmail.com (C.N.);

k.e.malterud@farmasi.uio.no (K.E.M.)

2 Department of Traditional Medicine, Institut National de Recherche en Santé Publique, BP 1746, Bamako, Mali; E-Mail: dri.diallo@yahoo.fr

* Authors to whom correspondence should be addressed; E-Mails: a.t.pham@farmasi.uio.no (A.T.P.); helle.wangensteen@farmasi.uio.no (H.W.); Tel.: +47-22-856-569 (A.T.P.);

Fax: +47-22-85-44-02 (A.T.P. \& H.W.).

Received: 3 July 2013; in revised form: 8 August 2013 / Accepted: 14 August 2013 /

Published: 26 August 2013

\begin{abstract}
Three flavone- $C$-glycosides - cassiaoccidentalin A (1), isovitexin (2) and isoorientin (3)-were isolated from the ethyl acetate (EtOAc) soluble fraction of the methanol crude extract of the African medicinal plant Biophytum umbraculum, This is the first report of these compounds in this plant. All compounds were identified by spectroscopic analysis and comparison with published data. Isoorientin (3) and the EtOAc extract showed the greatest antioxidant activity in the DPPH assay as well as the strongest inhibition of xanthine oxidase (XO) and 15-lipoxygenase (15-LO). From these results, the extract of $B$. umbraculum might be a valuable source of flavone $C$-glycosides.
\end{abstract}

Keywords: Biophytum umbraculum; flavone-C-glycosides; DPPH; xanthine oxidase; 15-lipoxygenase

\section{Introduction}

Biophytum umbraculum Welw. (common syn. Biophytum petersianum Klotzsch) (Oxalidaceae) is a slender annual herb distributed in tropical and subtropical Africa, and across to Asia and New Guinea. The aerial parts of the plant have several medicinal uses in Mali and other African countries [1]. 
Ethnopharmacological surveys on the use of $B$. umbraculum by practitioners in different districts in Mali (Bamako, Siby and Dioila) show that the plant is frequently used against cerebral malaria, but also against hemorrhoids, colonic ailments, wounds, stomach ache and fever [2-4]. In Nigeria the plant has been used against wounds, gonorrhea, urethral stones and stomach ache [1]. Other indications reported are constipation, hypertension, migraine, epilepsy, breathing difficulties and lack of fertility $[1,5,6]$. Various in vitro studies indicate that extracts of $B$. umbraculum may exert beneficial pharmaceutical effects on hypertension [5,7-10]. In addition, pectic polysaccharides isolated from $B$. umbraculum have demonstrated diverse effects on the immune system by virtue of complement fixation [3,4], activation of macrophages and dendritic cells [11], and modulation of intestinal Peyer's patch cells [12]. Phytochemical investigations on B. umbraculum have so far been restricted to polysaccharides $[3,4,11,12]$, although saponins of unknown structure have been stated to be present in aqueous extracts of the plant [13].

In the past decades, there has been a growing interest in antioxidants and free radical scavengers as they may have an important role in the prevention of pathologies in which reactive oxygen species (ROS) or free radicals are implicated, such as atherosclerosis, cardiovascular diseases (CVD), ischemia/reperfusion injury, neurodegenerative diseases and cancer [14,15]. As a part of an ongoing project on Malian medicinal plants [16-18], in the present study chemical characterization and investigation of antioxidant activity were performed on B. umbraculum.

\section{Results and Discussion}

\subsection{Isolation and Structural Elucidation}

Compounds 1, 2 and 3 were isolated from the EtOAc soluble fraction of the $\mathrm{MeOH}$ crude extract of Biophytum umbraculum by column chromatography (CC). Based on the weights of purified fractions, estimated concentrations of substances in the crude $\mathrm{MeOH}$ extract are $0.45 \%$ (1), $0.37 \%$ (2) and $0.17 \%$ (3). The compounds were identified as cassiaoccidentalin A (1), isovitexin (2) and isoorientin (3), respectively, by comparing their ${ }^{1} \mathrm{H}-\mathrm{NMR}$ and ${ }^{13} \mathrm{C}$-NMR spectroscopic data with those reported in the literature [19-21]. Besides, the COSY spectrum revealed ${ }^{1} \mathrm{H}-{ }^{1} \mathrm{H}$ couplings and helped assign proton resonances, especially those of the inner sugar of $\mathbf{1}$. The HSQC spectrum showed all ${ }^{1} \mathrm{~J}$ direct ${ }^{1} \mathrm{H}_{-}{ }^{13} \mathrm{C}$ correlations and thus confirmed the assignments of all signals arising from the $\mathrm{CH}$ - and $\mathrm{CH}_{2}$ - groups. Among all the ${ }^{1} \mathrm{H}_{-}{ }^{13} \mathrm{C}$ long-range correlations observed in the $\mathrm{HMBC}$ spectrum, the most important were the correlations from the anomeric proton of the inner sugar $\left(\mathrm{H}-1^{\prime}\right)$ to $\mathrm{C}-6\left({ }^{2} \mathrm{~J}\right), \mathrm{C}-5\left({ }^{3} \mathrm{~J}\right)$ and $\mathrm{C}-7\left({ }^{3} \mathrm{~J}\right)$ of the aglycone, which confirmed the $C$-glycosylation at C-6.

The chemical structures of the three flavone- $C$-glycosides are shown in Figure 1 . To our knowledge, this is the first identification of flavone- $C$-glycosides in B. umbraculum. Compound $\mathbf{1}$ is a very rare flavone- $C$-glycoside which has only been identified once before, in Cassia occidentalis [19], whereas the more common flavone glucosides $\mathbf{2}$ and $\mathbf{3}$ have been identified in another Biophytum species, namely Biophytum sensitivum [22]. 
Figure 1. Chemical structures of the three flavone- $C$-glycosides 1-3.
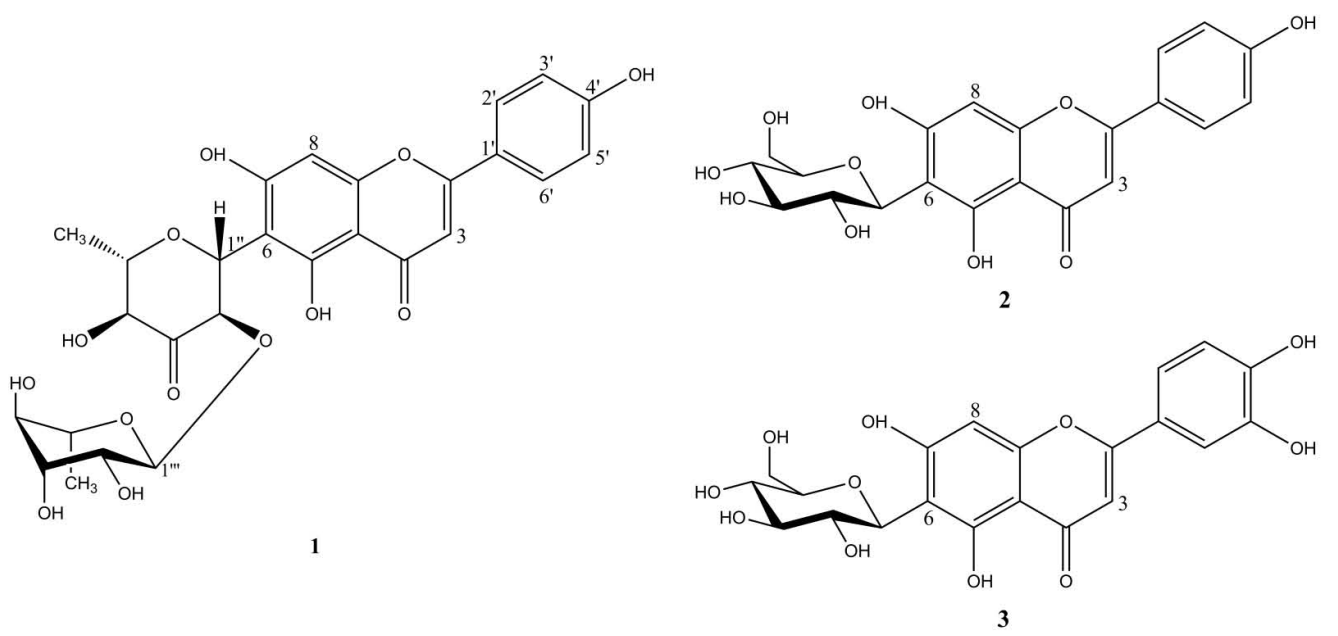

\subsection{Antioxidant Activity}

The dichloromethane (DCM) crude extract of $B$. umbraculum was virtually inactive as a DPPH radical scavenger, xanthine oxidase $(\mathrm{XO})$ and 15-lipoxygenase (15-LO) inhibitor $\left(\mathrm{IC}_{50}>167 \mu \mathrm{g} / \mathrm{mL}\right)$. The $\mathrm{MeOH}$ crude extract and the semi-polar extracts obtained by partitioning the $\mathrm{MeOH}$ extract showed fairly high radical scavenger activity and 15-LO inhibition (Table 1). The extracts showed moderate or low inhibitory activity towards XO compared to the positive control quercetin. The EtOAc extract exhibited the highest activity in all three assays.

Table 1. DPPH radical scavenging, xanthine oxidase (XO) inhibition and 15-lipoxygenase (15-LO) inhibition of Biophytum umbraculum extracts. $\mathrm{IC}_{50}$ values $\pm \mathrm{SD}$ (in $\mu \mathrm{g} / \mathrm{mL}$ ) are shown.

\begin{tabular}{cccc}
\hline Extract & DPPH & XO & 15-LO \\
\hline DCM crude extract & $>167$ & $>167$ & $>167$ \\
MeOH crude extract & $13.4 \pm 0.6$ & $59.7 \pm 6.1$ & $68.9 \pm 5.0$ \\
EtOAc extract & $6.8 \pm 0.6$ & $c a .21$ & $43.0 \pm 3.6$ \\
BuOH extract & $12.5 \pm 1.9$ & $102.6 \pm 5.6$ & $53.4 \pm 2.1$ \\
Aqueous residue & $29.8 \pm 3.5$ & $>167$ & $>167$ \\
Quercetin (positive control) & $4.4 \pm 0.4$ & $2.33 \pm 0.09$ & $33.4 \pm 0.3$ \\
\hline
\end{tabular}

The activity of the isolated compounds as DPPH scavengers, XO- and 15-LO inhibitors is shown in Table 2. Flavone- $C$-glycosides were found to contribute both as DPPH scavengers and 15-LO inhibitors in the EtOAc extract. This is in good accordance with previous structure-activity studies indicating the importance of a 2,3 double bond in conjugation with a 4-oxo function in the C-ring and $o$-dihydroxy structure in the B-ring [23,24]. The strongest inhibitor of XO and 15-LO and the best DPPH scavenger was isoorientin. The strong DPPH radical scavenging activity of isoorientin and the much weaker activity of isovitexin are supported by previous results $[25,26]$. This antioxidant activity clearly shows that the 3',4'-dihydroxy structural element of isoorientin is of importance for activity, isoorientin having an $\mathrm{IC}_{50}$ value similar to the positive control quercetin. This is in accordance with a 
previous report [27]. The EtOAc extract may contain additional unidentified XO inhibitors, since XO inhibition of the isolated compounds does not account for the activity observed in the EtOAc extract. It has previously been suggested that flavones without a glycosyl group were relatively strong inhibitors of XO, as the presence of a glycosyl group would decrease the inhibitory activity [28,29]. XO and 15-LO inhibitors may be beneficial for diseases and conditions such as ischemia/reperfusion, gout, renal stones, inflammation, arteriosclerosis, neurodegenerative diseases, cancer, aging, etc. [28,30-32]. Additionally, XO-inhibitors may have beneficial effects as adjuncts in the management of severe Plasmodium falciparum malaria [33].

Since the solubility in water of the flavonoids reported here is unknown (although a calculation, as given on the SciFinder website, gives theoretical values of between 0.12 and $0.15 \mathrm{mg} / \mathrm{mL}$ ), an analysis of aqueous extracts of the plant may be relevant for the evaluation of its ethnopharmacological use, and might thus represent a useful continuation of the present work.

These results imply that the extracts from $B$. umbraculum are a rich source of flavone- $C$-glycosides, and that herbal remedies obtained from this plant may have an effect against inflammations or other diseases related to oxidative stress. The results from our study would seem to be in accord with several of the reported ethnopharmacological usages of the plant.

Table 2. Effects of isolated compounds from B. umbraculum on DPPH radical scavenging, xanthine oxidase $(\mathrm{XO})$ inhibition and 15-lipoxygenase (15-LO) inhibition. $\mathrm{IC}_{50}$ values $\pm \mathrm{SD}$ (in $\mu \mathrm{M}$ ) are shown.

\begin{tabular}{cccc}
\hline Isolated compound & DPPH & XO & 15-LO \\
\hline Cassiaoccidentalin A (1) & $>167$ & $149.5 \pm 7.4$ & $99.9 \pm 2.5$ \\
Isovitexin (2) & $96.0 \pm 3.6$ & $>167$ & $107.1 \pm 2.1$ \\
Isoorientin (3) & $18.1 \pm 1.1$ & $117.2 \pm 13.5$ & $86.4 \pm 0.5$ \\
Quercetin (positive control) & $13.7 \pm 1.3$ & $7.7 \pm 0.3$ & $110.6 \pm 1.0$ \\
\hline
\end{tabular}

\section{Experimental}

\subsection{General}

1D and 2D NMR spectra were recorded on Bruker DPX 300 or Bruker AVII 400 instruments with $\mathrm{CD}_{3} \mathrm{OD}$ as solvent and TMS as internal standard. CC was done over Sephadex LH-20 (Pharmacia) or reverse phase (RP) silica (VersaPak C18 cartridges; Supelco). Fractions from CC were combined as indicated by TLC. Foils coated with Si gel RP-18 $\mathrm{F}_{254 \mathrm{~S}}$ (Merck) were used for analytical and preparative TLC. In analytical TLC, spots were visualized by UV irradiation (254 and $366 \mathrm{~nm}$ ) and by spraying with $\mathrm{Ce}\left(\mathrm{SO}_{4}\right)_{2}\left(1 \%\right.$ in $10 \%$ aqueous $\left.\mathrm{H}_{2} \mathrm{SO}_{4}\right)$ followed by heating $\left(100{ }^{\circ} \mathrm{C}, 10-15 \mathrm{~min}\right)$. For UV/VIS measurements, a Biochrom Libra S32 PC instrument was employed.

\subsection{Plant Material}

Flowering, whole aerial parts of Biophytum umbraculum Welw. (Oxalidaceae) were collected in Blendio, Mali. The plant was identified by one of the authors, Prof. Drissa Diallo. A voucher specimen 
(NO. 2653 DMT) was deposited in the herbarium at the Department of Traditional Medicine (DMT), Bamako, Mali.

\subsection{Extraction and Isolation}

The dried and powdered aerial parts of B. umbraculum $(305 \mathrm{~g})$ were extracted at RT with DCM $(4 \times 2.5 \mathrm{~L})$, each time for $24 \mathrm{~h}$, yielding $5.1 \mathrm{~g}$ of DCM extract $(1.7 \%$ yield $)$. The plant residue was then extracted similarly with $\mathrm{MeOH}(5 \times 2.5 \mathrm{~L})$ to yield $17.7 \mathrm{~g}(5.8 \%)$ of $\mathrm{MeOH}$ extract. The $\mathrm{MeOH}$ extract was suspended in $3 \times 100 \mathrm{~mL}$ distilled water and successively partitioned with EtOAc $(6 \times 300 \mathrm{~mL})$ and $\mathrm{BuOH}(5 \times 200 \mathrm{~mL})$. The solvents were removed under vacuum, affording an EtOAc extract $(4.6 \mathrm{~g})$, a $\mathrm{BuOH}$ extract $(5.3 \mathrm{~g})$ and an aqueous residue $(5.0 \mathrm{~g})$. The EtOAc (E) extract was chromatographed over Sephadex LH-20 $(2.5 \times 74 \mathrm{~cm})$ with a gradient of $\mathrm{H}_{2} \mathrm{O} / \mathrm{MeOH}(25 \%-100 \%$ $\mathrm{MeOH})$ to yield 15 subfractions (E1-E15). E9 (334 mg), E10 (1,029 mg) and E11 (555 mg) were chosen for isolation of bioactive compounds based on fraction weights, pattern in NMR spectra and results from activity assays. E9 was flash chromatographed over RP C-18 Si gel (VersaPak, $2.3 \times 11 \mathrm{~cm}$ ) eluting with a $\mathrm{H}_{2} \mathrm{O}-\mathrm{MeOH}$ gradient $(40 \%-100 \% \mathrm{MeOH})$ to give $1(57 \mathrm{mg})$. E10 was applied to a RP C-18 Si gel VersaPak column $(4 \times 15 \mathrm{~cm})$ and eluted with a gradient of $\mathrm{H}_{2} \mathrm{O}-\mathrm{MeOH}$ $(20 \%-100 \% \mathrm{MeOH})$ to afford E10.1-E10.9. E10.6 (42 mg) and E10.7 (24 mg) were combined and rechromatographed over a smaller VersaPak column $(2.3 \times 11 \mathrm{~cm})$ with a $\mathrm{H}_{2} \mathrm{O}-\mathrm{MeOH}$ gradient $(20 \%-100 \% \mathrm{MeOH})$ followed by preparative TLC to give $2(8.8 \mathrm{mg})$. E11 was flash chromatographed with the same column as used for E10 and eluted with a gradient of $\mathrm{H}_{2} \mathrm{O}-\mathrm{MeOH}(40 \%-100 \% \mathrm{MeOH})$ to yield E11.1-E11.13. E11.2 (50 mg) and E11.3 (21 mg) were combined and purified using the same system to give $3(6.5 \mathrm{mg})$. A second batch of plant material (225 g) was subjected to Soxhlet extraction ( $2 \mathrm{~L} \mathrm{DCM}$ for $48 \mathrm{~h}$, followed by $3 \mathrm{~L} \mathrm{MeOH}$ for $48 \mathrm{~h}$ ). Yield of DCM extract was $7.5 \mathrm{~g}(3.3 \%$ ), and of $\mathrm{MeOH}$ extract $17.2 \mathrm{~g}(7.6 \%)$. EtOAc extract (4.6 g), BuOH extract (3.3 g) and aqueous residue $(5.1 \mathrm{~g})$ were obtained similarly as above.

\subsection{DPPH Radical Scavenging}

Pure substances and crude extracts (Soxhlet) were dissolved in DMSO, and the assay was carried out as reported previously [34]. Quercetin (Sigma-Aldrich) was used as positive control.

\subsection{Inhibition of Xanthine Oxidase (XO)}

Pure substances and crude extracts (Soxhlet) were dissolved in DMSO, and the assay was carried out as reported previously [35]. Quercetin (Sigma-Aldrich) was used as positive control.

\subsection{Inhibition of 15-Lipoxygenase (15-LO)}

Pure substances and crude extracts (Soxhlet) were dissolved in DMSO, and the assay was carried out as reported previously [34]. Quercetin (Sigma-Aldrich) was used as positive control.

\subsection{Statistical Analysis}

All samples were analyzed in triplicates and the results are shown as mean \pm standard deviation (SD). 


\section{Conclusions}

Our phytochemical study led to the isolation and characterization of three flavone- $C$-glycosides from the aerial parts of B. umbraculum. This is the first report on this type of compound from this plant. Compound $\mathbf{3}$ and the EtOAc extract of the plant revealed strong antioxidant activity towards DPPH radical and 15-LO, and moderate activity towards XO. Further studies on these extracts with respect to antioxidant properties in vivo are needed.

\section{Acknowledgments}

The NMR laboratory at the Chemistry Department, University of Oslo, Norway is acknowledged for the spectrometer facilities.

\section{Conflicts of Interest}

The authors declare no conflict of interest.

\section{References}

1. Burkill, H.M. The Useful Plants of West Tropical Africa, 2nd ed.; Royal Botanic Gardens, Kew: Surrey, UK, 1997; Volume 4, pp. 336-338.

2. Grønhaug, T.E.; Glæserud, S.; Skogsrud, M.; Ballo, N.; Bah, S.; Diallo, D.; Paulsen, B.S. Ethnopharmacological survey of six medicinal plants from Mali, West-Africa. J. Ethnobiol. Ethnomed. 2008, 4, 26.

3. Inngjerdingen, K.T.; Coulibaly, A.; Diallo, D.; Michaelsen, T.E.; Smestad, P.B. A complement fixing polysaccharide from Biophytum petersianum Klotzsch, a medicinal plant from Mali, West Africa. Biomacromolecules 2006, 7, 48-53.

4. Diallo, D.; Sogn, C.; Samaké, F.B.; Paulsen, B.S.; Michaelsen, T.E.; Keita, A. Wound healing plants in Mali, the Bamako region. An ethnobotanical survey and complement fixation of water extracts from selected plants. Pharm. Biol. 2002, 40, 117-128.

5. Mouzou, A.P.; Titrikou, S.; Constantin, B.; Sebille, S.; Cognard, C.; Gbeassor, M.; Raymond, G. Effets du décocté de Biophytum petersianum (Oxalidaceae) sur la libération du calcium du réticulum sarcoplasmique des cellules musculaires squelettiques (in French). Phytothérapie 2010, 8, 231-235.

6. Focho, D.A.; Ndam, W.T.; Fonge, B.A. Medicinal plants of Aguambu-Bamumbu in the lebialem highlands, southwest province of Cameroon. Afr. J. Pharm. Pharmacol. 2009, 3, 1-13.

7. Kodjo, K.M.; Contesse, V.; Do, R.J.L.; Aklikokou, K.; Titrikou, S.; Gbeassor, M.; Vaudry, H. In vitro effects of crude extracts of Parkia biglobosa (Mimosaceae), Stereospermum kunthianum (Bignoniaceae), and Biophytum petersianum (Oxalidaceae) on corticosteroid secretion in rat. J. Steroid. Biochem. Mol. Biol. 2006, 100, 202-208.

8. Titrikou, S.; Eklu-Gadegbeku, K.; Mouzou, A.; Aklikokou, K.; Gbeassor, M. Calcium antagonistic activity of Biophytum petersianum on vascular smooth muscles of wistar rat. Iran. J. Pharmacol. Ther. 2007, 6, 185-189. 
9. Titrikou, S.; Aklikokou, A.K.; Gbeassor, M. Effets de l'extrait de Biophytum petersianum (Oxalidaceae), Klotzsh, sur le systeme cardiovasculaire de cobaye (in French). Pharmacopée et Médecine Traditionelle Africaines 1998, 10, 32-41.

10. Titrikou, S.; Eklu-Gadegbeku, K.; Aklikokou, K.A.; Gbeassor, M. Effets de Biophytum petersianum (Oxalidaceae) sur la pression artérielle chez le rat Wistar (in French). Phytothérapie 2008, 6, 215-218.

11. Inngjerdingen, M.; Inngjerdingen, K.T.; Patel, T.R.; Allen, S.; Chen, X.; Rolstad, B.; Morris, G.A.; Harding, S.E.; Michaelsen, T.E.; Diallo, D.; et al. Pectic polysaccharides from Biophytum petersianum Klotzsch, and their activation of macrophages and dendritic cells. Glycobiology 2008, 18, 1074-1084.

12. Grønhaug, T.E.; Kiyohara, H.; Sveaass, A.; Diallo, D.; Yamada, H.; Paulsen, B.S. Beta-D- $(1 \rightarrow 4)$-galactan-containing side chains in RG-I regions of pectic polysaccharides from Biophytum petersianum Klotzsch contribute to expression of immunomodulating activity against intestinal Peyer's patch cells and macrophages. Phytochemistry 2011, 72, 2139-2147.

13. Santoso, B.; Kilmaskossu, A.; Sambodo, P. Effects of saponin from Biophytum petersianum Klotzsch on ruminal fermentation, microbial protein synthesis and nitrogen utilization in goats. Anim. Feed Sci. Tech. 2007, 137, 58-68.

14. Valko, M.; Leibfritz, D.; Moncol, J.; Cronin, M.T.D.; Mazur, M.; Telser, J. Free radicals and antioxidants in normal physiological functions and human disease. Int. J. Biochem. Cell Biol. 2007, 39, 44-84.

15. Ghasemzadeh, A.; Ghasemzadeh, N. Flavonoids and phenolic acids: Role and biochemical activity in plants and human. J. Med. Plants Res. 2011, 5, 6697-6703.

16. Le, N.H.T.; Malterud, K.E.; Diallo, D.; Paulsen, B.S.; Nergard, C.S.; Wangensteen, H. Bioactive polyphenols in Ximenia americana and the traditional use among Malian healers. J. Ethnopharmacol. 2012, 139, 858-862.

17. Austarheim, I.; Mahamane, H.; Sanogo, R.; Togola, A.; Khaledabadi, M.; Vestrheim, A.C.; Inngjerdingen, K.T.; Michaelsen, T.E.; Diallo, D.; Paulsen, B.S. Anti-ulcer polysaccharides from Cola cordifolia bark and leaves. J. Ethnopharmacol. 2012, 143, 221-227.

18. Pham, A.T.; Dvergsnes, C.; Togola, A.; Wangensteen, H.; Diallo, D.; Paulsen, B.S.; Malterud, K.E. Terminalia macroptera, its current medicinal use and future perspectives. J. Ethnopharmacol. 2011, 137, 1486-1497.

19. Hatano, T.; Mizuta, S.; Ito, H.; Yoshida, T. C-glycosidic flavonoids from Cassia occidentalis. Phytochemistry 1999, 52, 1379-1383.

20. Ramarathnam, N.; Osawa, T.; Namiki, M.; Kawakishi, S. Chemical studies on novel rice hull antioxidants. 2. Identification of isovitexin, a C-glycosyl flavonoid. J. Agric. Food Chem. 1989, 37, 316-319.

21. Kumarasamy, Y.; Byres, M.; Cox, P.J.; Delazar, A.; Jaspars, M.; Nahar, L.; Shoeb, M.; Sarker, S.D. Isolation, structure elucidation, and biological activity of flavone 6-C-glycosides from Allaria petiolata. Chem. Nat. Compd 2004, 40, 122-128.

22. Bucar, F.; Jachak, S.M.; Karting, T.; Schubert-Zsilavecz, M. Phenolic compounds from Biophytum sensitivum. Pharmazie 1998, 53, 651-653. 
23. Rice-Evans, C.A.; Miller, N.J.; Paganga, G. Structure-antioxidant activity relationships of flavonoids and phenolic acids. Free Radical Biol. Med. 1996, 20, 933-956.

24. Waki, T.; Nakanishi, I.; Matsumoto, K.-i.; Kitajima, J.; Chikuma, T.; Kobayashi, S. Key role of chemical hardness to compare 2,2-diphenyl-1-picrylhydrazyl radical scavenging power of flavone and flavonol $O$-glycoside and $C$-glycoside derivatives. Chem. Pharm. Bull. 2012, 60, 37-44.

25. Yao, H.; Chen, Y.; Shi, P.Y.; Hu, J.; Li, S.G.; Huang, L.Y.; Lin, J.H.; Lin, X.H. Screening and quantitative analysis of antioxidants in the fruits of Livistona chinensis $\mathrm{R}$. Br using HPLC-DAD-ESI/MS coupled with pre-column DPPH assay. Food Chem. 2012, 135, 2802-2807.

26. Du, Q.Z.; Li, B. Identification of antioxidant compounds of Mucuna sempervirens by high-speed counter-current chromatographic separation-DPPH radical scavenging detection and their oestrogenic activity. Food Chem. 2012, 131, 1181-1186.

27. Zielinska, D.; Zielinski, H. Antioxidant activity of flavone $C$-glucosides determined by updated analytical strategies. Food Chem. 2011, 124, 672-678.

28. Hayashi, T.; Sawa, K.; Kawasaki, M.; Arisawa, M.; Shimizu, M.; Morita, M. Inhibition of cow's milk xanthine oxidase by flavonoids. J. Nat. Prod. 1988, 51, 345-348.

29. Lin, C.M.; Chen, C.S.; Chen, C.T.; Liang, Y.C.; Lin, J.K. Molecular modeling of flavonoids that inhibits xanthine oxidase. Biochem. Biophys. Res. Commun. 2002, 294, 167-172.

30. Da Silva, S.L.; da Silva, A.; Honorio, K.M.; Marangoni, S.; Toyama, M.H.; da Silva, A.B.F. The influence of electronic, steric and hydrophobic properties of flavonoid compounds in the inhibition of the xanthine oxidase. J. Mol. Struct. 2004, 684, 1-7.

31. Yigitkanli, K.; Pekcec, A.; Karatas, H.; Pallast, S.; Mandeville, E.; Joshi, N.; Smirnova, N.; Gazaryan, I.; Ratan, R.R.; Witztum, J.L.; et al. Inhibition of 12/15-lipoxygenase as therapeutic strategy to treat stroke. Ann. Neurol. 2013, 73, 129-135.

32. Del Rio, D.; Rodriguez-Mateos, A.; Spencer, J.P.E.; Tognolini, M.; Borges, G.; Crozier, A. Dietary (poly)phenolics in human health: Structures, bioavailability, and evidence of protective effects against chronic diseases. Antioxid. Redox Sign. 2013, 18, 1818-1892.

33. Iwalokun, B.A.; Bamiro, S.B.; Ogunledun, A. Levels and interactions of plasma xanthine oxidase, catalase and liver function parameters in Nigerian children with Plasmodium falciparum infection. APMIS 2006, 114, 842-850.

34. Wangensteen, H.; Samuelsen, A.B.; Malterud, K.E. Antioxidant activity in extracts from coriander. Food Chem. 2004, 88, 293-297.

35. Pham, A.T.; Malterud, K.E.; Paulsen, B.S.; Diallo, D.; Wangensteen, H. DPPH radical scavenging and xanthine oxidase inhibitory activity of Terminalia macroptera leaves. Nat. Prod. Commun. 2011, 6, 1125-1128.

Sample Availability: Samples of the compounds 1-3 are available from the authors.

(C) 2013 by the authors; licensee MDPI, Basel, Switzerland. This article is an open access article distributed under the terms and conditions of the Creative Commons Attribution license (http://creativecommons.org/licenses/by/3.0/). 